\section{Producing of concrete by using a dolomite waste as an alternative filler}

ALEKSANDRS KORJAKINS - Institute of Materials and Structures of Riga Technical University aleks@latnet.Iv

GenADIJS Š AHMENKo - Institute of Materials and Structures of Riga Technical University - gs@apollo.Iv

DiANA BAJARE - Institute of Materials and Structures of Riga Technical University - diana.bajare@rtu.Iv

SERGEJS GAIDUKovS - Institute of Polymer Materials of Riga Technical University - gaidukov@gmail.com

Danuta PIzEle - Institute of Polymer Materials of Riga Technical University - polmaterials@gmail.com

The object of this investigation is crushed dolomite waste that originally is mixture of sand and small size powder fractions. Investigation of physical and chemical property of material showed generally homogeneous mineralogical composition of waste: dolomite $\mathrm{CaMg}\left(\mathrm{CO}_{3}\right)_{2}$ content is not less than 92\%. Fine-graded and ordinary concrete materials were produced substituting quartz sand with dolomite waste sands. Frost resistance and compression strength of concrete specimens filled with dolomite waste are equal to the concrete filled with traditional quartz sand. Compositions filled with dolomite sand showed higher water absorption and water penetration. Investigations have shown the possibility utilization a dolomite sand waste as substitution of traditional quartz sands.

\section{Introduction}

Nowadays increased attention to such materials, which are storing in the large volume of waste materials staying at open dolomite stone cast mines and lime stone pits after technological production of building materials: gravel and fractioned crushed stones. Crushed stones are produced by development a large parent mass of rock. Thus, many secondary undesirable tiny aggregates (powders, sands) with features depending on the properties of the parent rock (e.g., chemical and mineralogical composition, specific gravity, hardness, strength, physical and chemical stability, pore structure and color) are considered.

Last years in Latvia remained tremendous large quantities of such technological wastes, as very tiny crushed sands, that needs to be recycled with maximum efficiency. For example, due to production of the crushed dolomites more than 10 million $\mathrm{m}^{3}$ of waste are accumulated at one open cast mine. During decades dolomite sand waste accumulates and is quantified in million tons nowadays. Produced waste mostly remains unused on quarries occupying place and increasing overall technological costs. Such situation demands integrated approach to the produced waste recycling possibilities [1-4].

There are many ways and possibilities to use investigated dolomite fraction or sands. It can be used in agriculture as lime substitute for soil treatment, as quartz sand equivalent in building industry and other. In turn, utilization of dolomite sand wastes in production technology of concrete has been proposed. By this work the continuous investigations aiming the preparation and testing of different concrete materials using different materials and also waste materials as fillers are started.

The aim of an investigation is developing technology for production concrete materials with properties are equivalent and even enhanced of traditional concrete. The investigation was focused on the determination of structure-property regularities of the produced material, which is vitally important. Waste sands mineralogical composition is characterized using wide angle X-ray diffraction analysis (WAXD), sand
Aleksandrs Korjakins is professor of Riga Technical University, Faculty of Civil Engineering since 2006. A. Korjakins received doctor degree in 1997 in the field mechanics of Solid and Diploma of Civil engineer in 1985. Fields of research: fracture toughness of composites, numerical methods and computer analysis of structures, building materials, constructions, recycling. Up to date are published more than 50 scientific publications.

Genadijs Šahmenko is researcher at Riga Technical University Faculty of Civil Engineering. Scientific interests are building materials, constructions, recycling of building materials, high-strength concrete. G. Šahmenko has received doctor degree in the field of Material science at 2004. PhD concerned to the design of concrete mixture. Up to date are published more than 10 publications.

Diana Bajare

is associate professor of Riga Technical University, Faculty of Civil Engineering since 2007. She was a PhD student of Riga Technical University, Faculty of Chemical Technology in 1996-2001. D. Bajare received doctor Degree in 2001. Fields of interest: ceramics, building materials, recycling of industrial waste. Up to date are published more than 20 publications.

Sergejs Gaidukovs is researcher at Riga Technical University Faculty of Material Science and Applied Chemistry. Scientific interests are nanophase and nanostructured materials, hybrid organic-inorganic materials, polymers and construction materials. S.Gaidukovs has received $\mathrm{PhD}$ in the field of Material Science at October, 2008. PhD concerned to the investigation of nanostructured polymeric materials. Up to date are published more than 10 publications.

Danuta Pizele

is PhD student at Riga Technical University Faculty of Material Science and Applied Chemistry. Scientific interests are polymer blends with polyolefins, polymers and composites. D. Pizele is a member (GradIMMM) of IOM (Institute of Materials, Minerals and Mining) 2008. Investigations have being carried within the field of polymers, material science, material testing. Several publications have been issued.

size distribution is analyzed using powder grading and laser scattering analysis of its suspension. Differential thermal analysis (DTA) and thermal gravimetric analysis (TGA) of the dolomite waste are also performed. All these properties have an important influence on the quality of fresh and hardened concrete. The new compositions of produced concrete material have been created by modifying initial quantities of dolomite sand additive in the composition. Compression strength, water absorption and density properties of produced concrete material are investigated.

\section{Experimental methods}

\section{Materials}

Dolomite is supplied from the open cast mine in Latvia. Before usage and investigations dolomite sand is preliminary remixed for homogeneity and dried in closed oven at $105 \pm 5^{\circ} \mathrm{C}$. Drying conditions of the dolomite powder are chosen correspondingly to the preliminary investigations performed by DTA-TGA analysis.

Finally concrete filled with quartz and dolomite sands has been prepared. Concrete mixtures were cast into oiled steel cube shape moulds according to [5] and kept till complete 
solidification. Produced concrete specimens were further tested in accordance with LVS EN12390-3:2002 [6].

\section{Testing}

Specimens of the selected dolomite waste are investigated using several experimental methods. The particle size parameters of dolomite sand are found from data of the grading and laser scattering experiments, while observation of the dolomite temperature transitions during heating realized by the DTA-TGA (Fig. 1.).

The waste specimen's mineralogical structure was examined by the method of X-ray diffraction. The X-ray diffraction measurements were carried out on a Bruker diffractometer at a temperature of $20^{\circ} \mathrm{C}$. The $\mathrm{CuK}_{\alpha}$-monochromatic radiation with a wave length of $\lambda=0,154 \mathrm{~nm}$ in the range of diffraction angles $2 \theta$ from 4 to $50^{\circ}$ was used. The scanning rate was $2 \mathrm{deg} /$ $\min$.

The calorimetric tests were carried out by DTA on a Paulig DTA instrument. The specimens about $10 \mathrm{mg}$ in weight were heated in an inert atmosphere at a rate of $10^{\circ} \mathrm{C} / \mathrm{min}$ in the temperature range from room temperature to $1000^{\circ} \mathrm{C}$. The thermogravimetric tests by the method of TGA were performed also on a Paulig instrument. Specimens about $10 \mathrm{mg}$ in weight were heated in an inert atmosphere up to $1000^{\circ} \mathrm{C}$. The dolomite powder thermal stability was evaluated from the weight-loss curves.

For identification of dolomite particle sizes we choose, firstly, sieving (also with additional washing) using sieve set equipped with mechanic vibration table and secondly, further for smaller fraction less than $63 \mu \mathrm{m}$ laser scattering or turbidity analyses.

The compressive strength tests of concrete were performed on compression testing equipment. Testing was taken according to the standard LVS EN 12390-3:2002 for three samples of each composition after 7 - and 28-day aging period.

Water penetration under pressure was performed according to LVS EN 12390-8:2002. Specimens were placed into experimental testing equipment and aged at pressure $500 \mathrm{kPa}$ for 72 hours.

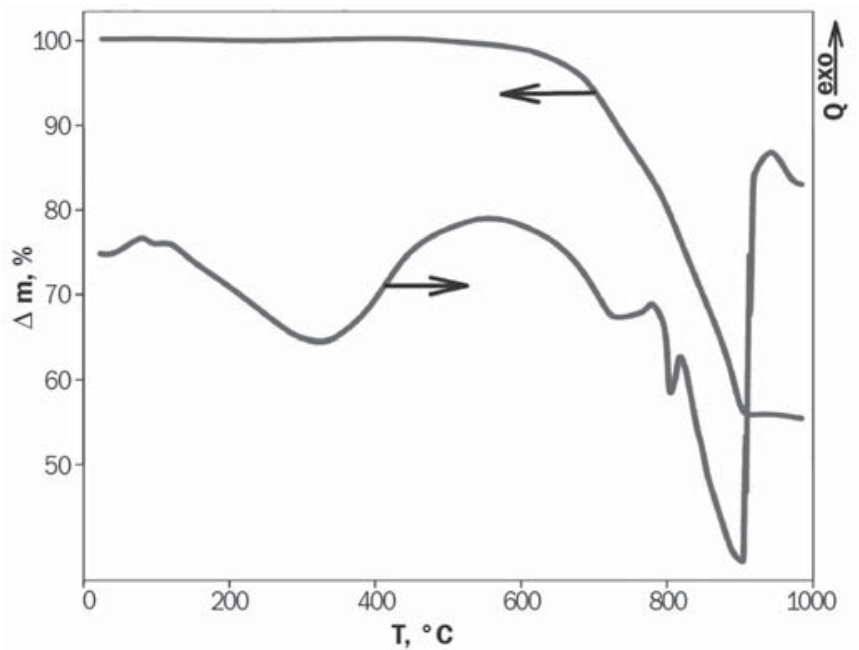

Fig. 1. DTA-TGA thermographs of dolomite waste

1. ábra Dolomit hulladék DTA-TGA görbéi

\section{Results and discussions}

\section{Dolomite waste properties}

Mineralogical composition of dolomite waste has been obtained by X-ray diffraction. The pattern indicates that the main components of the investigated composition are dolomite $\mathrm{CaCO}_{3} \times \mathrm{MgCO}_{3}$ and small amounts of quartz $\mathrm{SiO}_{2}-2,5 \%$ and calcite $\mathrm{CaCO}_{3}-1,5 \%$. There is no evidence of clay minerals being present in the mix. It is obvious that dolomite by nature is kind of the primary sediment mineral and has the wide spread geologic distribution [7]. The chemical formula of dolomite is $\mathrm{CaCO}_{3} \times \mathrm{MgCO}_{3}$ with the averaged chemical composition. Results were obtained from the chemical analysis according to LVS EN 1744-1 which shows that dolomite is 92\%, oxides $\mathrm{CaO} \sim 31 \%, \mathrm{MgO} \sim 17 \%$ and the other oxides which in total are less than $1 \%$ of the weight of the raw material $-\mathrm{Fe}_{2} \mathrm{O}_{3}-0,34 \%$, $\mathrm{Al}_{2} \mathrm{O}_{3}-0,64 \%, \mathrm{Na}_{2} \mathrm{O}-0,82 \%, \mathrm{~K}_{2} \mathrm{O}-0,76 \%, \mathrm{SO}_{3}-0,05 \%$.

The DTA-TGA analysis shows typical decomposition process of dolomite (water physical adsorption and water chemical debonding from material and separating up of the material into constituent parts) increasing the temperature. The resolving process of dolomite occurs at the temperature interval from about $590^{\circ} \mathrm{C}$ to $900^{\circ} \mathrm{C}$, which is presented by the endothermic reaction peaks at DTA curve. The maximum weight loss reaches $45 \%$ what is attributed to emission of $\mathrm{CO}_{2}$. The products of dolomite decomposition are $\mathrm{MgO}, \mathrm{CaO}$ and $\mathrm{CO}_{2}$. This process is accompanied by the following chemical reaction:

$730-740^{\circ} \mathrm{C}$

$900^{\circ} \mathrm{C}$

$\mathrm{CaCO}_{3} \times \mathrm{MgCO}_{3} \rightarrow \mathrm{MgO}+\mathrm{CO}_{2} \uparrow+\mathrm{CaCO}_{3} \rightarrow \mathrm{MgO}+\mathrm{CaO}+2 \mathrm{CO}_{2}$

Two different concretes have been prepared: fine-graded concretes D1-D5 contain dolomite and traditional quartz sands varying from 0 till 100\%, ordinary concretes D6 and D7 with dolomite waste and traditional quartz sand. Produced concrete compositions D1-D7 are shown in Table 1. Concrete mixture components are homogenized in concrete mixer after that necessary water quantity was added.

\begin{tabular}{|c|c|c|c|c|c|c|c|}
\hline \multirow[b]{2}{*}{ Mix designation } & \multicolumn{5}{|c|}{$\begin{array}{l}\text { Fine-graded } \\
\text { concrete }\end{array}$} & \multicolumn{2}{|c|}{$\begin{array}{l}\text { Norm. } \\
\text { concrete }\end{array}$} \\
\hline & D1 & D2 & D3 & D4 & D5 & D6 & D7 \\
\hline $\begin{array}{l}\text { Dolomite sand, \% by } \\
\text { total sand content }\end{array}$ & 0 & 25 & 50 & 75 & 100 & 0 & 100 \\
\hline \multicolumn{8}{|c|}{ Concrete mixture compositions, $\mathrm{kg} / \mathrm{m}^{3}$} \\
\hline Portland cement & 380 & 380 & 380 & 380 & 380 & 350 & 350 \\
\hline Gravel, 2-10mm & - & - & - & - & - & 1038 & 1038 \\
\hline $\begin{array}{l}\text { Quartz based sand } \\
\text { of fraction } 0 / 4 \mathrm{~mm}\end{array}$ & 1324 & 1000 & 676 & 331 & - & & \\
\hline $\begin{array}{l}\text { Quartz based sand } \\
\text { of fraction } 0 / 0,5 \mathrm{~mm}\end{array}$ & 234 & 177 & 120 & 59 & - & 138 & - \\
\hline $\begin{array}{l}\text { Remina dolomite } \\
\text { sand }\end{array}$ & - & 381 & 762 & 1169 & 1558 & - & - \\
\hline $\begin{array}{l}\text { Plavinas dolomite } \\
\text { sand }\end{array}$ & - & - & - & - & - & - & 724 \\
\hline Water & 245 & 256 & 260 & 264 & 269 & 212 & 224 \\
\hline
\end{tabular}

Table 1. Concrete mixture compositions

1. táblázat A betonkeverékek összetétele 
Optimized compositions of concretes D6 and D7 are developed by modern methodology using particle size distribution data of all concrete contaminants (gravel, quartz sands, and dolomite waste) presented in Fig. 2. Different fillers take $60-80 \%$ of concrete volume and the granulometry of the fillers has great influence on material final features. Optimal compositions of concrete are calculated. The granulometric compositions curves of produced concrete D6 and D7 are located in the region between ordinal dotted curves.

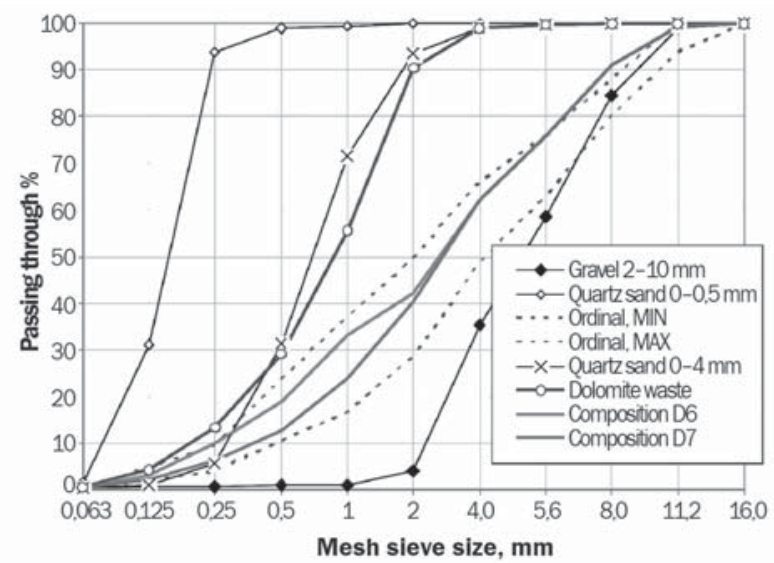

Fig. 2. Particle size distribution of concrete composition

2. ábra A beton összetételek szemcseméret eloszlása

\section{Fresh and hardened concrete properties}

Analyzing the fresh concrete mix properties such as cement/ water ratio, cone flow and cone slump, can be concluded that concrete filled with dolomite sand involves additional water content. Thus the cement/water ratio has been changed for keeping necessary concrete mix consistency. Cement/water ratio slightly enlarges from 0,69 till 0,76 increasing dolomite content in the specimens D1- D5.

Cone flow and cone slump of the concrete mix are decreasing from $190 \mathrm{~mm}$ (D1) to $172 \mathrm{~mm}$ (D5) and $105 \mathrm{~mm}$ (D1) to $80 \mathrm{~mm}$ (D5) correspondingly. Concrete compositions D6 and D7 are characterized with coarse particle content and lower values of cement/water ratio. Obviously, dolomite sands, initially having semicrystalline nature particles, can quite homogeneously disperse in the volume of the growing concrete stone and develop rigid spatial interpenetrated network that causes increasing overall strength in fresh and hardened concrete. Such effect of dolomite additive to the fresh concrete mortars is owed to the changes of qualitative and quantitative characteristics of concrete stone structure formation during the intrinsic hydration reaction process. The properties of fresh concrete are shown in Table 2.

\begin{tabular}{|c|c|c|c|c|c|c|c|}
\hline $\begin{array}{l}\text { Mix } \\
\text { designation }\end{array}$ & D1 & D2 & D3 & D4 & D5 & D6 & D7 \\
\hline $\begin{array}{l}\text { Dolomite sand, } \\
\% \text { by total sand } \\
\text { content }\end{array}$ & 0 & 25 & 50 & 75 & 100 & 0 & 100 \\
\hline \multicolumn{8}{|c|}{ Fresh concrete mortars properties } \\
\hline $\begin{array}{l}\text { Cement/water } \\
\text { ratio }\end{array}$ & 0,69 & 0,72 & 0,74 & 0,75 & 0,76 & 0,61 & 0,64 \\
\hline Cone flow, $\mathrm{mm}$ & 190,00 & 185,00 & 185,00 & 180,00 & 172,00 & - & - \\
\hline Cone slump, $\mathrm{mm}$ & 105,00 & 100,00 & 105,00 & 90,00 & 80,00 & 70,00 & 70,00 \\
\hline
\end{tabular}

Density of concrete compositions D1-D5 remains unaffected from the dolomite content. The compositions D1-D5 showed a little more water absorption for compositions with dolomite sand.

Compression strength of the compositions D6 and D7 remains the same after 7 and 28 days in spite of higher water/ cement ratio in dolomite sand filled concrete D7, what could be an effect of the dolomite additive to the fresh concrete mortars due to changes of the qualitative and quantitative characteristics of the concrete stone structure formation during the intrinsic hydration reaction process. Some authors presuppose development of the novel hydration complex phase on the interface of the cement and dolomite particles, that is featured as the semicrystalline high adhesion and the density complex epitaxial phase $[7,8]$. Tension strength of the compositions D6 and D7 is 2,28 and 2,31 MPa. Water penetration of D6 is $20,5 \mathrm{~mm}$ and of D7 - 32,0 mm. Physical and mechanical properties of the hardened concrete are shown in the Table 3. It was shown by the testing that compositions filled with dolomite sand have the same frost resistance as compositions with traditional sand.

\begin{tabular}{lccccccc}
$\begin{array}{l}\text { Mix designa- } \\
\text { tion }\end{array}$ & D1 & D2 & D3 & D4 & D5 & D6 & D7 \\
$\begin{array}{l}\text { Dolomite sand, } \\
\text { \% from total } \\
\text { sand content }\end{array}$ & 0 & 25 & 50 & 75 & 100 & 0 & 100 \\
\hline \multicolumn{7}{c}{ Concrete properties } \\
\hline Density, kg/m ${ }^{3}$ & 2196,0 & 2170,0 & 2229,0 & 2173,0 & 2229,0 & 2301,0 & 2335,0 \\
\hline $\begin{array}{l}\text { Compression } \\
\text { strength after } \\
7 \text { days, MPa }\end{array}$ & 16,5 & 16,0 & 16,0 & 16,4 & 17,4 & 19,5 & 20,8 \\
\hline $\begin{array}{l}\text { Compression } \\
\text { strength after } \\
\text { 28 days, MPa }\end{array}$ & 27,0 & 27,1 & 26,8 & 28,4 & 28,6 & 32,3 & 31,5 \\
\hline $\begin{array}{l}\text { Water } \\
\text { absorbtion, \% }\end{array}$ & 6,8 & 8,2 & 8,3 & 8,0 & 7,8 & - & - \\
\hline $\begin{array}{l}\text { Frost resis- } \\
\text { tance, cycles }\end{array}$ & $\mathrm{F} 100$ & $\mathrm{~F} 100$ & $\mathrm{~F} 100$ & $\mathrm{~F} 100$ & $\mathrm{~F} 100$ & $\mathrm{~F} 150$ & $\mathrm{~F} 150$ \\
\hline
\end{tabular}

Table 3. Hardened concrete properties

3. táblázat A megszilárdult betonok tulajdonságai

\section{Conclusions}

Compositions filled with dolomite sands consume additional water quantity to maintain homogeneous fresh mortar concrete properties. Compositions filled by dolomite sand and quartz sand in different proportions have equal compressions strength values in comparison with traditional concretes: $\sim 16$ $17 \mathrm{MPa}$ and $\sim 26-28 \mathrm{MPa}$ after 7 and 28 days, correspondingly. Compositions with dolomite sands had higher water absorption than compositions with traditional sand.

Concrete composition filled with dolomite sand wastes has the same frost resistance as composition filled with ordinary quartz sand. In the same time, composition with dolomite sand wastes has higher water penetration under pressure.

Based on above mentioned results it is concluded that investigated dolomite sand waste can be used as quartz sand equivalent material to produce concrete with set of properties (cone flow, cone slump, compression strength, water 
penetration, density) very close to traditional concrete filled by quartz sand.

\section{Acknowledgement}

The financial support of Ministry of Educational and Science of Republic of Latvian and Riga Technical University is acknowledged.

\section{References}

[1] V. Mymrin - S. M. Correa: New construction material from concrete production and demolition wastes and lime production waste, Construction and Building Materials, 21, 578-582, 2007

[2] H. Donza - O. Cabrera - E.F. Irassar: High-strength concrete with different fine aggregate, Cement and Concrete Research, 32, 1755-1761, 2002

[3] L.A. Diaza - R. Torrecillasa - A.H. De Azab - P. Penab - S. De Azab: Alumina-rich refractory concretes with added spinel, periclase and dolomite: A comparative study of their microstructural evolution with temperature, Journal of the European Ceramic Society, 25, 1499-1506, 2005

[4] Bülent Yllmaz - Asim Olgun: Studies on cement and mortar containing low-calcium fly ash, limestone, and dolomitic limestone, Cement and Concrete Composites, 30, Issue 3, 194-201, 2008

[5] Sacietējuša betona testēšana, 2.daļa: Stiprības testu paraugu izgatavošana un cietināšana, LVS EN 12390-2:2002, 2002
[6] Sacietējuša betona testēšana, 3.daḷa: Testa paraugu spiedes stiprība, LVS EN12390-3:2002, 2002

[7] Wypych George: ChemTec, Handbook of Fillers. 2nd ed., Publishing, 2000.

[8] Xu Lingling - Deng Min: Dolomite used as raw material to produce $\mathrm{MgO}$ based expansive agent, Cement and Concrete Research, 35, 1480-1485, 2005

\section{Betonkészítés dolomit hulladék alternatív töltőanyagként való felhasználásával}

E kutatás a homokszem nagyságú és poros frakciókból álló dolomit ôrlemény vizsgálatával foglalkozik. Az anyag fizikai és kémiai tulajdonságainak vizsgálata alapján a hulladék általánosságban homogén ásványi összetételû: a dolomit - $\operatorname{CaMG}\left(\mathrm{CO}_{3}\right)_{2}$ - tartalom legalább 92\%. Finomszemcsés és hagyományos betonokat készítettünk, amelyekben a kvarchomokot a dolomit hulladékkal helyettesítettük. A kvarchomok helyett dolomit hulladékot tartalmazó betonminták fagyállósága és nyomószilárdsága megegyezett a hagyományos, kvarchomokkal készített betonokéval. A dolomithulladék töltôanyagú betonok erôsebb víz abszorpciót és vízbehatolást mutatnak. A kutatások alapján lehetôség nyílik a hagyományos kvarchomoknak hulladék dolomithomokkal való helyettesítésére a betonokban. 